Revista de
Economild
Contemporâned

\title{
EVOLUÇÃO DA DÍVIDA E DA NECESSIDADE DE FINANCIAMENTO DO SETOR PÚBLICO NO BRASIL (1995-2016): UM BALANÇO DO PERÍODO PÓS-REAL
}

\author{
Giuliano Contento de Oliveira ${ }^{a}$ \\ Daniel Arias Vazquez \\ Paulo José Whitaker Wolf \\ aProfessor do Instituto de Economia da Universidade Estadual de Campinas (IE-UNICAMP).

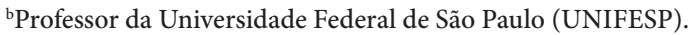 \\ 'Doutorando em Economia no IE-UNICAMP.
}

Artigo recebido em 20/01/2016 e aprovado em 09/06/2017.

RESUMO: O objetivo deste artigo consiste em analisar a trajetória do endividamento e da necessidade de financiamento do setor público brasileiro entre 1995 e 2016, a partir de três grandes períodos, quais sejam, 1995-2002, 2003-2008, 2009-2014 e 20152016. Pode-se verificar que as condições externas altamente benignas, tanto em termos dos preços das commodities como do ingresso líquido de fluxos internacionais de capital para a economia brasileira, foram imprescindíveis para a melhora dos indicadores fiscais na economia brasileira, a saber, necessidades de financiamento, dívida líquida e dívida bruta, todos em relação ao PIB. No período mais recente, a deterioração do quadro macroeconômico e a consequente maior dificuldade de se viabilizar a geração de superavit fiscal primário mais elevado têm suscitado novos e complexos desafios para a gestão das contas públicas no Brasil.

PALAVRAS-CHAVE: contas públicas; dívida líquida do setor público; necessidade de financiamento do setor público; liquidez internacional; Brasil.

CLASSIFICAÇÃO JEL: H60; H62; H63.

Correspondência para: Giuliano Contento de Oliveira

Contato: giulianoliveira@gmail.com 


\title{
DEBT AND BORROWING REQUIREMENTS OF THE BRAZILIAN PUBLIC SECTOR (1995-2016): AN ASSESSMENT OF THE POST-REAL PERIOD
}

\begin{abstract}
The aim of this paper is to analyze the debt and borrowing requirements trajectories of the Brazilian public sector between 1995 and 2016, considered from the point of view of three major periods, that is, 1995-2002, 2003-2008, 2009-2014, and 2015-2016. It can be observed that singular external conditions, both in terms of commodity prices and of net inflows of international capitals to the Brazilian economy, were essential for the improvement of its main fiscal indicators, namely, the borrowing requirements, the gross debt and the net debt, all considered in relation to GDP. More recently, the deterioration of the macroeconomic environment and the greater difficulty to generate higher primary fiscal surpluses have caused new and complex challenges for public accounts management in Brazil.
\end{abstract}

KEYWORDS: public accounts; public sector net debt; public sector borrowing requirements; international liquidity; Brazil. 


\section{INTRODUÇÃO}

A partir de 1999, no contexto do abandono da âncora cambial e da assunção do sistema de metas para a inflação e do regime de câmbio flutuante, passou a prevalecer na economia brasileira uma deliberada política de geração de superavit fiscais primários. Entretanto, isso não foi capaz de evitar o crescimento da Dívida Líquida do Setor Público (DLSP) em relação ao PIB até 2003. Foi somente a partir de então que essa razão passou a cair.

Nesse sentido, este artigo tem o objetivo de discutir o endividamento e as necessidades de financiamento do setor público no Brasil entre 1995 e 2016, buscando-se realizar um balanço do período posterior ao Plano Real.

Como se sabe, os indicadores fiscais são considerados rigorosamente pelas agências de classificação de risco para avaliar a capacidade de os governos honrarem os seus compromissos ${ }^{1}$. Quanto melhoro rating do país, menor é o risco de crédito para os credores em caso de default. Essas notas, assim, buscam apurar a probabilidade de suspensão do pagamento dos juros e do principal da dívida na data de seu vencimento, bem como de sua troca ou reestruturação involuntária ${ }^{2}$.

Argumenta-se que as condições externas singulares que prevaleceram a partir de 2003, com exceção do período imediatamente posterior à deflagração da crise global, em 2008, foram determinantes para a melhora dos indicadores fiscais na economia brasileira, pois concorreram para: i) reduzir a dívida externa líquida do setor público; ii) acelerar o crescimento econômico; iii) introduzir uma tendência de apreciação cambial e permitir, dessa forma, a viabilização de uma tendência declinante da taxa Selic entre o final de 2006 e 2013, mesmo em contexto de crescimento econômico (com exceção de 2009), fator que reduziu a carga de juros incidente sobre a dívida do setor público; e iv) aumentar a arrecadação tributária. Com a reversão dessas condições a partir do aprofundamento da crise global iniciada em 2008, as contas públicas

\footnotetext{
1 As agências de classificação de risco se desenvolveram consideravelmente a partir dos anos de 1970, diante do avanço dos processos de abertura e integração dos mercados financeiros nacionais e de securitização de dívidas públicas e privadas. Elas ganharam força com a expansão da securitização de recebíveis e com a implementação dos Acordos de Basileia II, que consideram os ratings para a composição dos ativos dos bancos, dado o seu capital próprio. Mas a atuação dessas agências depende, em grande medida, da sua reputação - seriamente abalada pelas crises do final da década de 1990 e início da década de 2000 e, principalmente, pela crise global deflagrada em 2008.

2 Vale lembrar que o Brasil recebeu o "grau de investimento" da Standard and Poor's em 30 de abril de 2008. A Fitch elevou a nota do país em maio de 2008 e a Moody's em setembro de 2009. Em setembro de 2015, por seu turno, a agência Standard and Poor's reduziu a nota do Brasil, que perdeu a condição de "grau de investimento", em grande medida por conta da deterioração dos indicadores fiscais do país.
} 
no Brasil passaram a sofrer pressões relevantes, especialmente a partir de 2015, quando a economia brasileira entra em uma profunda recessão.

$\mathrm{O}$ artigo está dividido em três seções, além desta introdução e da conclusão. A primeira aborda o padrão de inserção do Brasil na economia global. Já a segunda apresenta os principais indicadores fiscais da economia brasileira, bem como os indicadores externos considerados para explicar o comportamento das contas públicas no país. Por fim, a terceira seção discute o papel desempenhado pela expansão da liquidez e pela redução das taxas de juros internacionais, bem como pela variação dos preços das commodities, na determinação da trajetória da NFSP/PIB, da DBGG/PIB e da DLSP/ PIB nos períodos de 1995 a 2002, 2003 a 2008, 2009 a 2014 e 2015 a 2016.

\section{A INSERÇÃO DA ECONOMIA BRASILEIRA NA GLOBALIZAÇÃO}

A “agenda neoliberal" iniciou-se no final dos anos de 1970, defendendo que o livre funcionamento dos mercados seria suficiente para garantir o desenvolvimento das economias. A sua implementação estabeleceu uma nova ordem internacional, com o aumento substancial da mobilidade de bens, serviços e capitais, por meio do maior grau de abertura comercial e financeira das economias. Por meio da primeira, buscou-se expor as economias nacionais à concorrência externa, de sorte a estimular a competitividade. Já por meio da abertura financeira, esperava-se: i) reduzir os riscos envolvidos nas decisões econômicas, diante da maior diversificação das carteiras de ativos; ii) viabilizar o acesso à "poupança externa"; e iii) disciplinar a política econômica, pois políticas inadequadas geram fuga de capitais e elevação das taxas de juros (OBSTFELD e TAYLOR, 2004).

Esse novo arranjo, contudo, implicou importantes efeitos adversos sobre as economias periféricas, notadamente em função das características de suas estruturas produtivas e da natureza hierárquica e assimétrica do sistema monetário e financeiro internacional contemporâneo (PRATES, 2005; OLIVEIRA, 2012). De fato, os países em que os setores intensivos em trabalho e recursos naturais possuem importância não desprezível na economia experimentaram pressões no sentido da especialização na produção e exportação de produtos menos sofisticados. Além disso, os países de moedas fracas e mercados financeiros menos profundos tiveram uma redução do grau de autonomia de suas políticas econômicas, relativamente aos desenvolvidos, de moedas internacionalmente conversíveis e mercados financeiros maduros ${ }^{3}$.

\footnotetext{
3 Em suma, a moeda é inconversível porque não tem aceitação no mercado internacional, dado que o sistema
} monetário internacional é hierarquizado e assimétrico. Sobre essa questão, ver Prates (2005) e Oliveira (2012). 
A comparação da forma de inserção da maior parte das economias latino-americanas na economia mundial, entre as quais a economia brasileira, com o padrão de inserção internacional das economias asiáticas em desenvolvimento permite evidenciar a existência de ao menos dois padrões distintos de política econômica. Os países asiáticos mantiveram o controle sobre os fluxos de capitais e o gerenciamento da concorrência, através do controle do governo sobre as decisões de investimento e o direcionamento de crédito. Já o padrão latino-americano foi de corte liberal-conservador, cujas diretrizes são o livre mercado (abertura comercial e financeira) e a redução da intervenção estatal na economia. Essas diferenças certamente contribuíram para as distintas performances econômicas entre os países asiáticos e latino-americanos nos últimos trinta anos (AKYUZ, 2005).

No caso brasileiro, a abertura financeira contribuiu para o plano de estabilização de preços com âncora cambial. Mas o ingresso de capital estrangeiro de curto prazo, ao mesmo tempo em que permitiu o financiamento das contas externas, aumentou a vulnerabilidade externa da economia. Nos períodos de restrição da liquidez internacional, a aversão ao risco provocou fuga de capitais, resultando em elevação dos prêmios de risco (juros) e/ou pressão para a desvalorização cambial.

\section{DÍVIDA PÚBLICA E NFSP DEPOIS DO PLANO REAL (1995-2014)}

A evolução das contas públicas no Brasil, nas duas décadas que se seguiram ao lançamento do Plano Real, pode ser analisada a partir de quatro períodos, a saber, 1995-2002, 2003-2008, 2009-2014 e 2015-2016, considerando-se as variáveis deficit público e dívida pública. Em todos esses intervalos, com destaque ao segundo, as trajetórias do deficit público e da dívida pública em relação ao PIB foram influenciadas em grande medida, pelas condições externas. O ambiente externo favorável contribuiu para a melhora das contas públicas porque, principalmente, contribuiu para acelerar o crescimento econômico, estimular a arrecadação e viabilizar a geração de superavit fiscal primário, propiciou expressivo acúmulo de reservas internacionais e concorreu para permitir a redução da taxa básica de juros e, assim, da carga de juros sobre a dívida pública.

\subsection{INDICADORES FISCAIS ANALISADOS}

A análise das contas públicas depois do Plano Real realizada tomou como referência os seguintes indicadores: Necessidade de Financiamento do Setor Público (NFSP)/ PIB, Dívida Bruta do Governo Geral (DBGG)/PIB e Dívida Líquida do Setor Público 
(DLSP)/PIB 4 . Analisou-se tanto a NFSP no conceito primário, isto é, a diferença entre as receitas e despesas do setor público com exceção dos gastos com juros, como no conceito nominal, ou seja, o resultado primário menos o pagamento de juros nominais. Já a DBGG diz respeito ao total de débitos ou passivos do governo geral, que compreende os governos federal, estadual e municipal (incluindo a administração direta e indireta e o INSS). Por fim, a DLSP diz respeito ao total de débitos ou passivos menos o total de créditos ou ativos do setor público ${ }^{5}$.

A Tabela 1 apresenta a NFSP acumulada nos últimos 12 meses, a DBGG e a DLSP em relação ao PIB, para o período 1995 a 2016. A NFSP mostra o resultado primário, os juros nominais e o resultado nominal, ao passo que a DBGG e a DLSP mostram a dívida total, segmentadas entre dívidas interna e externa. Para todos os indicadores considerados, os dados até 2001 incluem a Petrobras e a Eletrobras e são apresentados com o PIB valorizado pelo IGP-DI centrado. Já os dados a partir de 2002 não incluem as empresas estatais federais e são apresentados com o PIB em valores correntes. Essa diferença metodológica entre os dois períodos se deve ao fato de que os dados incluindo a Petrobras e a Eletrobras, bem como os dados com valores constantes, não são disponíveis na base utilizada, do BCB, para todo o período considerado.

A Tabela 2, por seu turno, apresenta a DLSP a partir da DBGG para o período de 2001 a 2016, em função da disponibilidade dos dados. Dessa forma, parte-se da dívida bruta dos governos federal, estadual e municipal, composta pela dívida interna e pela dívida externa desses entes, deduzindo-se desse valor os principais créditos internos e os principais créditos externos deles para se chegar à Dívida Líquida do Governo Geral (DLGG). Desde 2008, esta rubrica também inclui as chamadas "equalizações cambiais", referentes aos resultados financeiros das operações com derivativos cambiais e com reservas cambiais realizados pelo $\mathrm{BCB}$ e transferidos para o TN no final de cada período. A soma da dívida líquida do governo geral com a dívida líquida do BCB e das empresas estatais resulta na Dívida Líquida do Setor Público (DLSP) consolidado.

Deve-se registrar que houve uma mudança na metodologia de cálculo da dívida bruta e da dívida líquida do governo geral a partir de 2008. Até 2007, eram considera-

4 Enquanto a NFSP é uma variável de fluxo, a DLSP e a DBGG são variáveis de estoque.

5 Enquanto o governo geral compreende os governos federal, estadual e municipal (incluindo a administração direta e indireta e o INSS), o setor público consolidado compreende também o BCB e as empresas estatais federais, estaduais e municipais (permanecendo daí excluídos os bancos públicos, entretanto). Os dados para a dívida bruta são apresentados apenas para o governo geral, pois, ao contrário da NFSP e da DLSP, eles não estão disponíveis para o setor público consolidado.

Cumpre registrar a inexistência de uma série histórica harmônica no interregno considerado, a partir da base de dados disponível no site do BCB na internet. Por isso, a utilização de diferentes metodologias na apresentação dos indicadores. 
dos na dívida bruta interna todos os títulos emitidos pelo TN na carteira do BCB, independentemente de eles serem ou não utilizados nas operações compromissadas para fins de política monetária ${ }^{6}$. A partir de 2008, contudo, passaram a ser considerados na DBGG apenas os títulos emitidos pelo TN que são utilizados pelo BCB nas operações compromissadas. Os títulos livres na carteira do BCB são considerados apenas no cálculo da dívida líquida. Dessa forma, a nova metodologia reduz a dívida bruta em relação à metodologia anterior, ainda que mantenha inalterada a dívida líquida do governo geral ${ }^{7}$.

As Tabelas 1 e 2 demonstram que o setor público brasileiro obteve superavit primários acima de 3\% do PIB entre 1999 e 2008, mas a redução mais contundente da DLSP ocorreu apenas a partir de 2003, induzida, fundamentalmente, pela redução das dívidas bruta e líquida externas. De fato, a redução da dívida líquida apenas não foi maior em função do aumento das dívidas bruta e líquida internas do setor público, decorrente, sobretudo, do aumento da dívida mobiliária no mercado e no BCB, uma trajetória que se acentuou nos últimos anos e que está no interior da piora das contas públicas no Brasil no período mais recente.

6 O BCB usa os títulos públicos para a realização de operações de mercado aberto, utilizadas para viabilizar o alcance de sua meta operacional, qual seja, o atingimento da meta para a taxa Selic estipulada pelo Comitê de Política Monetária (Copom).

7 A alteração é justificada sob o argumento de que apenas os títulos de dívida utilizados nas operações do BCB devem ser incorporados ao cálculo da dívida bruta, uma vez que apenas eles representam uma "dívida fiscal efetiva”. Os títulos não utilizados nessas operações não teriam a mesma conotação de aplicação financeira, uma vez que o BCB não adquire esses papeis como forma de remunerar as suas disponibilidades e não é de seu interesse demandar o seu resgate (BCB, 2008). Essa alteração pode ser questionada, entretanto, uma vez que, por definição, a dívida líquida diferencia-se da dívida bruta apenas pelo fato de incorporar os ativos do governo geral e não novos passivos, como a nova metodologia acaba implicando. Por essa razão, para todo o período, optou-se por se considerar nesse artigo a metodologia anterior, em consonância com a contabilidade praticada no resto do mundo e defendida pelas instituições multilaterais.

Deve-se observar, ainda, que a partir de 2002, depois da Lei de Responsabilidade Fiscal, o TN passou a emitir títulos e a transferi-los para o BCB para que eles fossem utilizados em suas operações com o mercado. 
Tabela 1 - NFSP, DBGG e DLSP no Brasil (em \% do PIB, 1995-2016)

\begin{tabular}{|c|c|c|c|c|c|c|c|c|c|}
\hline & \multicolumn{3}{|c|}{$\begin{array}{l}\text { Necessidade de Financiamento do } \\
\text { Setor Público consolidado }\end{array}$} & \multicolumn{3}{|c|}{ Dívida Bruta do Governo Geral } & \multicolumn{3}{|c|}{$\begin{array}{l}\text { Dívida Líquida do Setor Público } \\
\text { consolidado }\end{array}$} \\
\hline & $\begin{array}{c}\text { Resultado } \\
\text { nominal } \\
\text { (A) }\end{array}$ & $\begin{array}{c}\text { Juros } \\
\text { nominais } \\
\text { (B) }\end{array}$ & $\begin{array}{c}\text { Resultado } \\
\text { primário } \\
(\mathrm{C}=\mathrm{A}-\mathrm{B})\end{array}$ & $\begin{array}{l}\text { Dívida } \\
\text { Bruta } \\
\text { Interna } \\
\text { (D) }\end{array}$ & $\begin{array}{c}\text { Dívida } \\
\text { Bruta } \\
\text { Externa } \\
\text { (E) } \\
\end{array}$ & $\begin{array}{c}\text { Dívida } \\
\text { Bruta } \\
\text { Total } \\
(\mathrm{F}=\mathrm{D}+\mathrm{E})\end{array}$ & $\begin{array}{c}\text { Dívida } \\
\text { Líquida } \\
\text { Interna } \\
(G)\end{array}$ & $\begin{array}{c}\text { Dívida } \\
\text { Líquida } \\
\text { Externa } \\
(\mathrm{H})\end{array}$ & $\begin{array}{c}\text { Dívida } \\
\text { Líquida } \\
\text { Total } \\
(\mathrm{I}=\mathrm{G}+\mathrm{H})\end{array}$ \\
\hline 1995 & 6,5 & 6,8 & $-0,3$ & - & - & - & 22,9 & 5,1 & 28,0 \\
\hline 1996 & 5,3 & 5,3 & 0,1 & - & - & - & 27,1 & 3,6 & 30,7 \\
\hline 1997 & 5,5 & 4,6 & 0,9 & - & - & - & 27,9 & 4,0 & 31,8 \\
\hline 1998 & 7,0 & 7,0 & 0,0 & - & - & - & 28,7 & 4,0 & 38,9 \\
\hline 1999 & 5,3 & 8,2 & $-3,0$ & - & - & - & 35,2 & 9,4 & 44,5 \\
\hline 2000 & 3,4 & 6,6 & $-3,3$ & - & - & - & 36,5 & 9,0 & 45,5 \\
\hline 2001 & 3,4 & 6,6 & $-3,2$ & 53,5 & 13,8 & 67,3 & 42,0 & 9,5 & 51,5 \\
\hline 2002 & 4,4 & 7,6 & $-3,2$ & 57,0 & 19,1 & 76,1 & 44,4 & 15,6 & 59,9 \\
\hline 2003 & 5,2 & 8,4 & $-3,2$ & 57,5 & 14,1 & 71,5 & 43,2 & 11,0 & 54,3 \\
\hline 2004 & 2,9 & 6,6 & $-3,7$ & 56,8 & 11,3 & 68,0 & 42,4 & 7,8 & 50,2 \\
\hline 2005 & 3,5 & 7,3 & $-3,7$ & 58,2 & 8,8 & 67,0 & 44,8 & 3,1 & 47,9 \\
\hline 2006 & 3,6 & 6,7 & $-3,2$ & 58,3 & 6,2 & 64,6 & 47,6 & $-1,2$ & 46,5 \\
\hline 2007 & 2,7 & 6,0 & $-3,2$ & 58,7 & 4,3 & 63,0 & 51,8 & $-7,3$ & 44,5 \\
\hline 2008 & 2,0 & 5,3 & $-3,3$ & 56,8 & 4,7 & 61,4 & 48,3 & $-10,7$ & 37,6 \\
\hline 2009 & 3,2 & 5,1 & $-1,9$ & 61,4 & 3,3 & 64,7 & 49,7 & $-8,8$ & 40,9 \\
\hline 2010 & 2,4 & 5,0 & $-2,6$ & 59,6 & 2,8 & 62,4 & 47,2 & $-9,3$ & 38,0 \\
\hline 2011 & 2,5 & 5,4 & $-2,9$ & 58,2 & 2,5 & 60,6 & 46,8 & $-12,3$ & 34,5 \\
\hline 2012 & 2,3 & 4,4 & $-2,2$ & 58,9 & 2,7 & 61,6 & 45,1 & $-12,9$ & 32,2 \\
\hline 2013 & 3,0 & 4,7 & $-1,7$ & 56,8 & 2,8 & 59,6 & 43,9 & $-13,4$ & 30,5 \\
\hline 2014 & 6,0 & 5,4 & 0,6 & 58,3 & 3,3 & 61,6 & 46,2 & $-13,6$ & 32,6 \\
\hline 2015 & 10,2 & 8,4 & 1,9 & 67,3 & 4,4 & 71,7 & 54,8 & $-19,2$ & 35,6 \\
\hline 2016 & 9,0 & 6,5 & 2,5 & 73,8 & 3,6 & 77,5 & 61,5 & $-15,4$ & 46,2 \\
\hline
\end{tabular}

Fonte: Elaboração própria com base em dados de BCB.

Tabela 2 - DBGG e DLSP (em \% do PIB, 2001-2016)

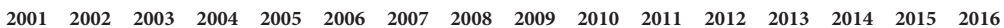

\begin{tabular}{|c|c|c|c|c|c|c|c|c|c|c|c|c|c|c|c|c|}
\hline $\begin{array}{l}\text { Dívida bruta do } \\
\text { governo geral (A) }\end{array}$ & 67,3 & 76,1 & 71,5 & 68,0 & 67,0 & 64,6 & 63,0 & 61,4 & 64,7 & 62,4 & 60,6 & 62,9 & 59,6 & 61,6 & 71,7 & 77,5 \\
\hline Dívida interna & 53,5 & 57,0 & 57,5 & 56,8 & 58,2 & 58,3 & 58,7 & 56,8 & 61,4 & 59,6 & 58,2 & 58,9 & 56,8 & 58,3 & 67,3 & 73,8 \\
\hline $\begin{array}{l}\text { Dívida } \\
\text { mobiliária no } \\
\text { mercado }\end{array}$ & 36,2 & 35,8 & 39,2 & 39,2 & 43,6 & 44,6 & 44,3 & 39,8 & 41,1 & 40,4 & 39,9 & 38,9 & 38,6 & 37,0 & 43,5 & 47,0 \\
\hline Outros1 & 2,9 & 2,2 & 2,2 & 2,1 & 1,7 & 1,4 & 1,2 & 1,1 & 1,2 & 1,1 & 1,1 & 1,2 & 0,2 & 2,0 & 2,4 & 2,5 \\
\hline Dívida externa & 13,8 & 19,1 & 14,1 & 11,3 & 8,8 & 6,2 & 4,3 & 4,7 & 3,3 & 2,8 & 2,5 & 2,7 & 2,8 & 3,3 & 4,4 & 3,6 \\
\hline
\end{tabular}


Tabela 2 - DBGG e DLSP (em \% do PIB, 2001-2016) (Continuação)

\begin{tabular}{|c|c|c|c|c|c|c|c|c|c|c|c|c|c|c|c|c|}
\hline & 2001 & 2002 & 2003 & 2004 & 2005 & 2006 & 2007 & 2008 & 2009 & 2010 & 2011 & 2012 & 2013 & 2014 & 2015 & 2016 \\
\hline Crédito interno & $-17,7$ & $-17,9$ & $-18,8$ & $-18,7$ & $-20,3$ & $-19,3$ & $-19,6$ & $-18,1$ & $-24,9$ & $-25,2$ & $-25,8$ & $-29,0$ & $-28,4$ & $-27,3$ & $-32,0$ & $-32,1$ \\
\hline $\begin{array}{l}\text { Disponibilidades } \\
\text { do governo } \\
\text { geral2 }\end{array}$ & $-7,7$ & $-7,0$ & $-7,9$ & $-9,0$ & $-10,6$ & $-10,3$ & $-11,2$ & $-9,4$ & $-13,4$ & $-11,6$ & $-12,1$ & $-14,2$ & $-13,6$ & $-11,7$ & $-15,7$ & $-17,5$ \\
\hline $\begin{array}{l}\text { Créditos às inst. } \\
\text { financeiras } \\
\text { oficiais }\end{array}$ & $-0,3$ & $-0,8$ & $-0,8$ & $-0,9$ & $-0,8$ & $-0,5$ & $-0,5$ & $-1,4$ & $-4,3$ & $-6,6$ & $-7,3$ & $-8,5$ & $-8,8$ & 9,4 & $-9,5$ & $-7,6$ \\
\hline Outros3 & $-9,7$ & $-10,1$ & $-10,1$ & $-8,8$ & $-8,9$ & $-8,5$ & $-7,9$ & $-7,3$ & $-7,2$ & $-7,0$ & $-6,4$ & $-6,3$ & $-6,0$ & $-25,0$ & $-6,8$ & $-7,0$ \\
\hline Crédito externo & $-0,3$ & $-0,4$ & $-0,2$ & $-0,2$ & $-0,2$ & 0,0 & 0,0 & 0,0 & 0,0 & 0,0 & 0,0 & 0,0 & 0,0 & 0,0 & 0,0 & 0,0 \\
\hline $\begin{array}{l}\text { Equalização } \\
\text { cambial (C) }\end{array}$ & - & - & - & - & - & - & - & $-5,5$ & 1,6 & 1,3 & 0,3 & 0,2 & $-0,1$ & $-1,1$ & $-1,8$ & 2,5 \\
\hline $\begin{array}{l}\text { Dívida liquida do } \\
\text { governo geral } \\
(D=A+B+C)\end{array}$ & 49,3 & 57,7 & 52,5 & 49,1 & 46,5 & 45,3 & 43,4 & 37,8 & 41,3 & 38,5 & 35,1 & 32,8 & 31,1 & 33,2 & 37,9 & 47,8 \\
\hline $\begin{array}{l}\text { Dívida líquida do } \\
\text { BCB (E) }\end{array}$ & $-0,6$ & $-0,4$ & $-0,3$ & $-0,4$ & 0,2 & 0,4 & 0,3 & $-1,0$ & $-1,2$ & $-1,1$ & $-1,2$ & $-1,2$ & $-1,2$ & $-1,2$ & $-3,1$ & $-2,5$ \\
\hline $\begin{array}{l}\text { Dívida líquida } \\
\text { das empresas } \\
\text { estatais (F) }\end{array}$ & 2,7 & 2,6 & 2,1 & 1,5 & 1,2 & 0,8 & 0,8 & 0,8 & 0,7 & 0,6 & 0,6 & 0,6 & 0,6 & 0,7 & 0,9 & 0,9 \\
\hline $\begin{array}{l}\text { Dívida líquida do } \\
\text { setor público } \\
(\mathrm{G}=\mathrm{D}+\mathrm{E}+\mathrm{F})\end{array}$ & 51,5 & 59,9 & 54,3 & 50,2 & 47,9 & 46,5 & 44,5 & 37,6 & 40,9 & 38,0 & 34,5 & 32,2 & 30,5 & 32,6 & 35,6 & 46,2 \\
\hline
\end{tabular}

Nota: ${ }^{1}$ Dívida bancária do governo federal, dívida assumida pela União Lei $n^{\circ} 8727$, dívida mobiliária dos governos estaduais, dívida bancária dos governos estaduais, outras dívidas estaduais, dívida mobiliária dos governos municipais e dívida bancária dos governos municipais; ${ }^{2}$ Aplicações da previdência social, arrecadação a recolher, depósitos à vista, disponibilidades do governo federal no BCB (notadamente, a conta única do TN) e aplicações na rede bancária; ${ }^{3}$ Aplicações de fundos e programas financeiros, créditos junto às estatais, demais créditos do governo federal e recursos do FAT na rede bancária.

Fonte: Elaboração própria com base em dados de BCB.

Já a Tabela 3 apresenta os principais indexadores da DLSP. Uma característica do mercado financeiro brasileiro, a saber, a institucionalidade da indexação financeira - o atrelamento dos títulos públicos à taxa Selic -, suscita a possibilidade de mudanças abruptas da composição da dívida pública mobiliária por indexador em função de mudanças nas expectativas dos proprietários de riqueza a respeito do comportamento futuro da taxa de câmbio, da taxa de inflação e da taxa de juros (OLIVEIRA, 2010a; OLIVEIRA e CARVALHO, 2010).

Juntamente com prazos mais curtos, a principal característica da DLSP é a importância da dívida pós-fixada e, dentre ela, da dívida indexada à taxa Selic. A redução desses papéis na composição da dívida mobiliária no mercado no período mais recente não se refletiu na melhora da composição da DLSP, em função da composição da dívida mobiliária na carteira do $\mathrm{BCB}$, em grande medida utilizada nas operações compromissadas realizadas por essa instituição com os títulos emitidos pelo TN. Isso dificulta a estratégia de mudança na composição da dívida pública, uma vez que os inves- 
tidores têm a alternativa de recorrer a essas operações para garantir a liquidez e rentabilidade de suas aplicações (SALTO e RIBEIRO, 2015).

Tabela 3 - DLSP por indexador (em \% do total, 2001-2016)

\begin{tabular}{lcccccccccccccccc}
\hline & $\mathbf{2 0 0 1}$ & $\mathbf{2 0 0 2}$ & $\mathbf{2 0 0 3}$ & $\mathbf{2 0 0 4}$ & $\mathbf{2 0 0 5}$ & $\mathbf{2 0 0 6}$ & $\mathbf{2 0 0 7}$ & $\mathbf{2 0 0 8}$ & $\mathbf{2 0 0 9}$ & $\mathbf{2 0 1 0}$ & $\mathbf{2 0 1 1}$ & $\mathbf{2 0 1 2}$ & $\mathbf{2 0 1 3}$ & $\mathbf{2 0 1 4}$ & $\mathbf{2 0 1 5}$ & $\mathbf{2 0 1 6}$ \\
\hline Câmbio & 43,7 & 39,1 & 26,9 & 17,9 & 6,8 & $-3,6$ & $-17,5$ & $-30,3$ & $-24,7$ & $-27,5$ & $-38,9$ & $-43,6$ & $-46,6$ & $-43,8$ & $-55,7$ & $-33,9$ \\
Preços & 9,4 & 10,5 & 12,3 & 13,9 & 16,2 & 23,4 & 27,1 & 32,2 & 29,5 & 30,3 & 34,8 & 43,2 & 44,9 & 41,9 & 42,2 & 34,1 \\
Selic & 37,2 & 46,2 & 51,1 & 49,5 & 49 & 42,3 & 47,8 & 59 & 62,8 & 63,5 & 69,8 & 64 & 62,2 & 68,8 & 78,5 & 72,6 \\
TR & 5,1 & 2,9 & 1,5 & 3,7 & 3,2 & 4,4 & 5,4 & 7,6 & 5,4 & 5,1 & 6,5 & 8,2 & 12 & 7,9 & 7,4 & 4,1 \\
TJLP & $-9,1$ & $-7,5$ & $-8,8$ & $-10,1$ & $-10,8$ & $-12,2$ & $-12,6$ & -15 & $-19,8$ & $-26,4$ & $-31,4$ & -36 & $-38,7$ & $-37,7$ & $-34,5$ & $-23,8$ \\
S/Remuneração & 6,5 & 7,4 & 7,2 & 8,5 & 9 & 9,9 & 11,2 & 11,6 & 11,4 & 13,2 & 13,4 & 14,1 & 14,6 & 13,5 & 11,4 & 8,9 \\
Pré-fixado & 7,2 & 1,5 & 9,8 & 16,6 & 26,6 & 35,8 & 38,6 & 34,8 & 35,3 & 41,8 & 45,8 & 50 & 51,7 & 49,6 & 50,8 & 37,9 \\
Outros & 0,0 & 0,0 & 0,0 & 0,0 & 0,0 & 0,0 & 0,0 & 0,0 & 0,0 & 0,0 & 0,0 & 0,0 & 0,0 & 0,0 & 0,0 & 0,0 \\
\hline
\end{tabular}

Nota: Principais componentes: i) cambial interna: BTN, CFT-D, NTN-M, NTN-A, NTN-D, NTN-I, NTN-R, NBCE, NBCF, FAT cambial; ii) cambial externa: dívida externa de todas as esferas, líquidas de reservas internacionais, garantias e disponibilidades externas; iii) Selic: LFT, LFT-A, LFT-B, operações compromissadas, aplicações financeiras e dívida bancárias de todas as esferas, dívidas securitizadas; iv) IGP-M: CFT-E, NTN-C, CTN; v) IGP-DI: CFT-A, renegociação de dívidas ao amparo da Lei n 8.729/1993, renegociação de dívidas com estados e municípios ao amparo da Lei no 9.496/1997, dívidas securitizadas e aplicações financeiras dos diversos segmentos; vi) IPCA: NTN-B; vii) TR: CFT-B, NTN-F, NTN-P, dívidas securitizadas, TODA, dívida bancária das diversas esferas, débitos e haveres da Emgea; viii) TJLP: fundos constitucionais, aplicações com recursos do FAT; ix) sem remuneração: depósitos à vista, arrecadação a recolher e base monetária; x) Prefixado: LTN, NTN-F e títulos de dívida externa emitidos em reais; xi) Outros: aplicações extra mercado.

Fonte: Elaboração própria com base em dados de BCB.

Por fim, a Tabela 4 apresenta os fatores condicionantes da DLSP, onde são consideradas as importâncias da variação da NFSP e, mais especificamente, da variação do resultado primário e dos juros nominais, da variação da taxa de câmbio, do reconhecimento de dívidas passadas, do processo de privatização do patrimônio público e da variação do PIB nas alterações da razão DLSP/PIB em cada ano considerado. Deve-se observar que a relevância da variação do PIB para a variação da DLSP/PIB pode ser calculada por resíduo, isto é, como a diferença entre a variação dessa razão e a variação dos demais fatores condicionantes considerados.

As excepcionais condições internacionais prevalecentes entre 2003 e 2008 e, também, ainda que em menor medida, entre 2010 e 2013, são fundamentais para entender o comportamento dos indicadores fiscais selecionados no Brasil. O expressivo ingresso líquido de recursos externos cumpriu papel altamente relevante para a trajetória da DLSP/PIB no país.

O Gráfico 1 apresenta a composição do saldo líquido da conta financeira do balanço de pagamentos do Brasil no período de 1995 a 2016. Verifica-se que a maior parte da melhora do saldo dessa conta durante a fase de expansão das finanças globais, entre 2004 e 2008, decorreu do aumento dos investimentos estrangeiros diretos, que acumularam saldo positivo de US\$ 63,6 bilhões nesse intervalo, e dos investimentos em carteira (títulos e ações), que somaram um superavit de US\$ 60,9 bilhões. 
Tabela 4 - Fatores condicionantes da DLSP (2002-2016)

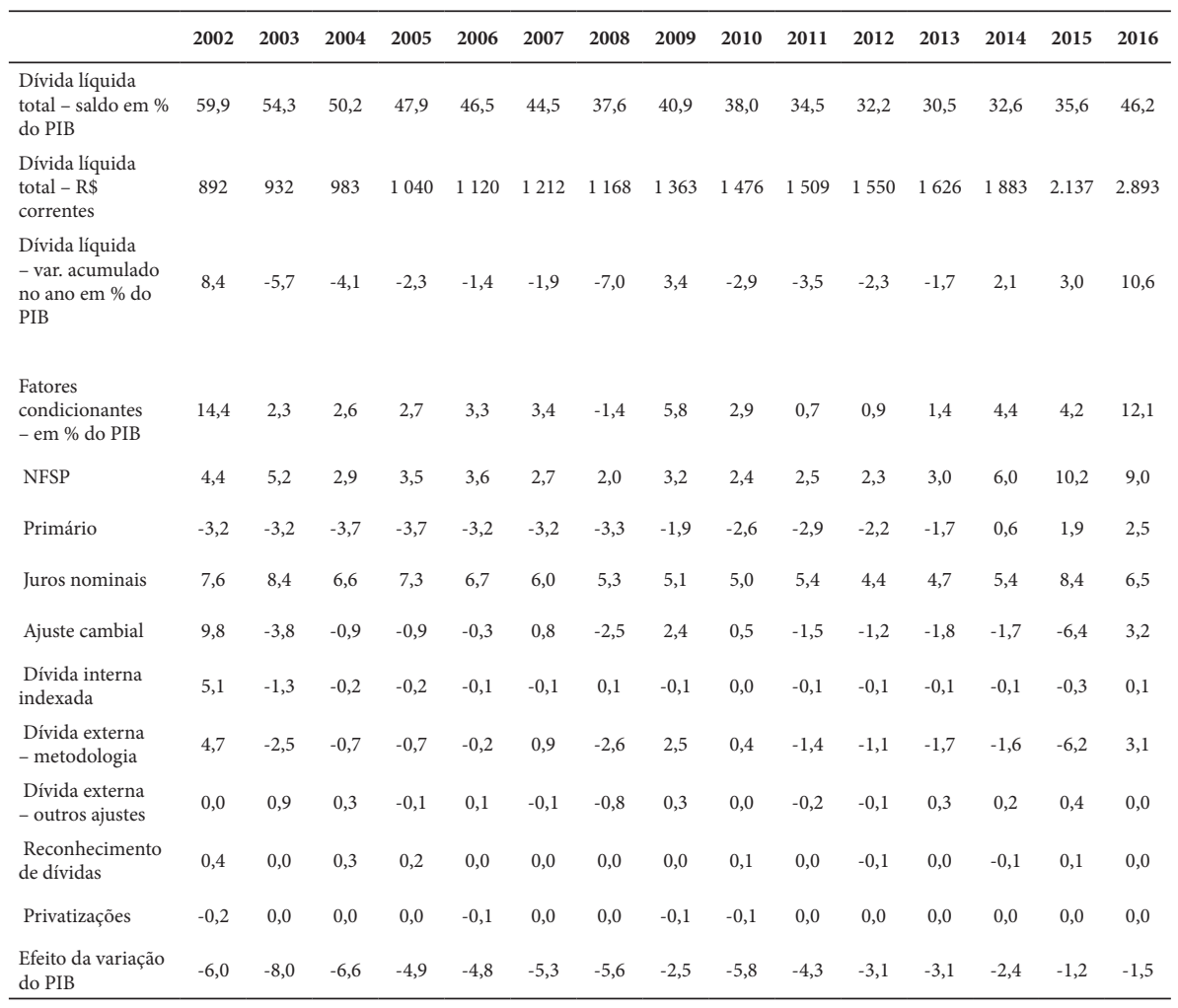

Fonte: Elaboração própria com base em dados de BCB.

\section{Gráfico 1 - Composição do saldo líquido da conta financeira (em US\$ bilhões, 1995-2016)}

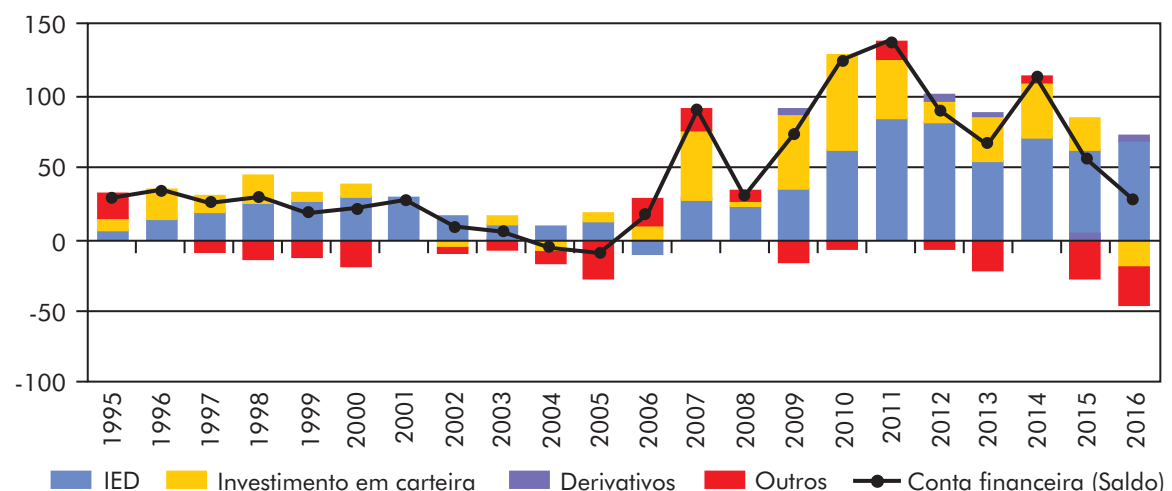

Fonte: Elaboração própria com base em dados de BCB. 
O Gráfico 2, por sua vez, mostra o diferencial entre a taxa básica de juros brasileira (taxa Selic) e norte-americana (Prime Rate) entre 2003 e 2016. Pode-se observar que, mesmo nos contextos de redução da taxa Selic, essa diferença permaneceu bastante elevada, tornando os títulos públicos no Brasil bastante atrativos relativamente àqueles emitidos por outros países.

Gráfico 2 - Taxa Selic, prime rate e diferencial de juros (2003-2016)

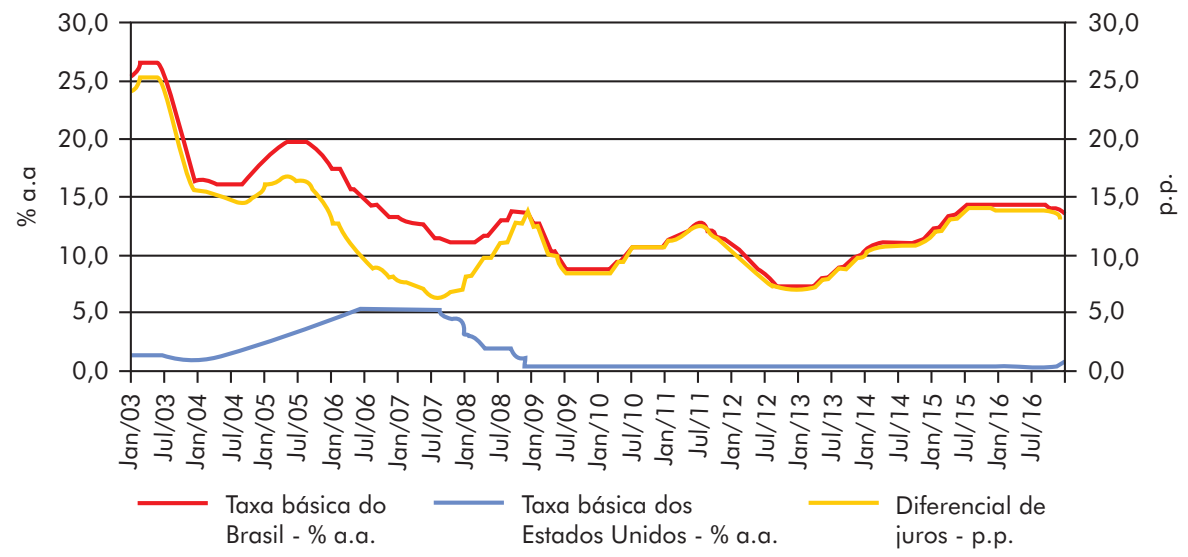

Fonte: Elaboração própria com base em dados de BCB.

Já o Gráfico 3 apresenta o saldo da conta de transações correntes do balanço de pagamentos, bem como o comportamento do quantum e dos preços das exportações da balança comercial e da trajetória dos preços das commodities medido pelo Índice de Preços das Commodities (CPI) - calculado pelo FMI e que inclui combustíveis e não combustíveis.

Verifica-se que, depois de permanecer praticamente estagnado entre 1995 e 2002, esse índice subiu de 100 para 265 entre 2003 e 2008. Ele voltou a se recuperar depois do aprofundamento da crise internacional e, em 2011, atingiu 296. A partir de então, iniciou uma trajetória de queda, atingindo apenas 154 em 2016, mesmo patamar de 2005. Por sua vez, a evolução do índice de preços das exportações brasileiras calculado pela Funcex acompanhou a trajetória do índice de preços das commodities durante todo o período considerado, em função da importância dos alimentos, das matériasprimas e dos recursos energéticos na pauta dos produtos vendidos pelo Brasil para o resto do mundo. 


\section{Gráfico 3 - Índice de preços das commodities (CPI), índice de preços e de quantum das exportações, conta de transações correntes e balança comercial brasileiras (1995-2016)}

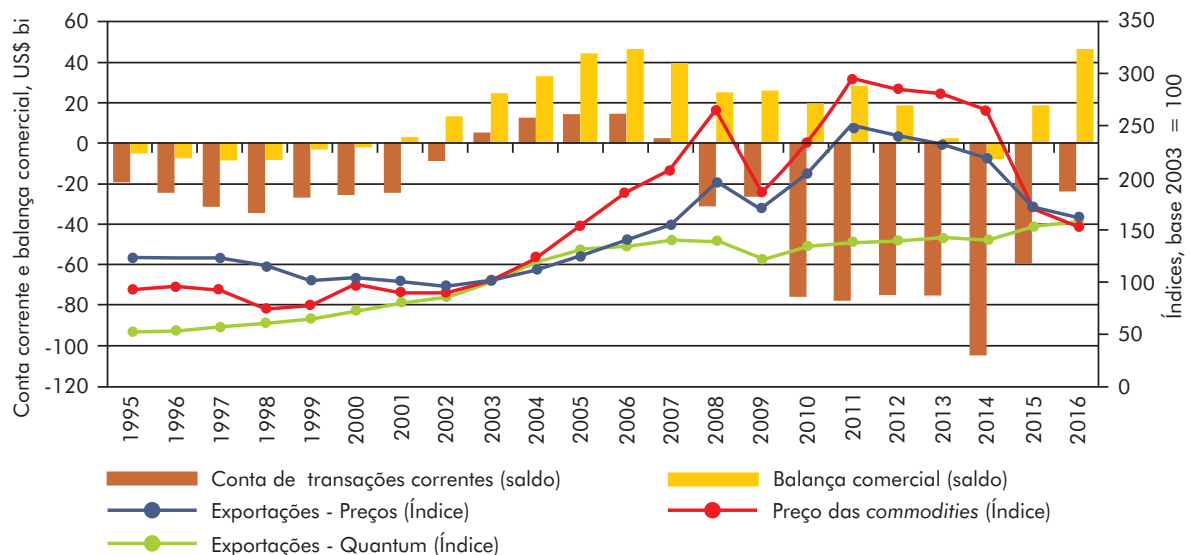

Fonte: Elaboração própria com base em dados de BCB.

O Gráfico 4, por seu turno, mostra a evolução do saldo da conta de transações correntes e da conta financeira do balanço de pagamentos, bem como das reservas internacionais e da dívida líquida do setor público no Brasil. Como consequência do superavit comercial e, sobretudo, do elevado ingresso líquido de capital estrangeiro, o BCB acumulou vultosas reservas internacionais entre 2006 e 2011. Mesmo com crescentes deficit em transações correntes, entre 2008 e 2012, as reservas internacionais do Brasil aumentaram de cerca de R 200 bilhões para cerca de R\$ 380 bilhões no período, em vista dos elevados saldos positivos verificados na conta financeira.

Essa acumulação de reservas internacionais resultou em uma expressiva queda da dívida externa líquida do setor público, como mostra o Gráfico 4. Ela caiu de aproximadamente US\$ 200 bilhões para cerca de - US\$ 800 bilhões entre 2002 e 2014, tornando a economia brasileira credora externa líquida do ponto de vista do endividamento do setor público. O aumento do ingresso líquido de capital estrangeiro propiciou o pagamento de grande parte dos compromissos acumulados pelo setor público em divisas, reduzindo a dívida externa bruta. Ademais, como as reservas internacionais constituem um ativo do BCB, a sua forte acumulação também reduziu a dívida externa líquida ${ }^{8}$.

8 Quando a acumulação de reservas internacionais é acompanhada pela valorização da taxa de câmbio, a dívida externa bruta cai ainda mais, em função da redução do seu valor em termos da moeda nacional. Deve-se notar, contudo, que as reservas internacionais impõem um custo de carregamento, determinado pelo diferencial de taxas de juros interna e externa. Sobre essa questão, ver IFI (2017). 


\section{Gráfico 4 - Conta de transações correntes, conta financeira, reservas internacionais e dívida externa líquida (1995-2016)}

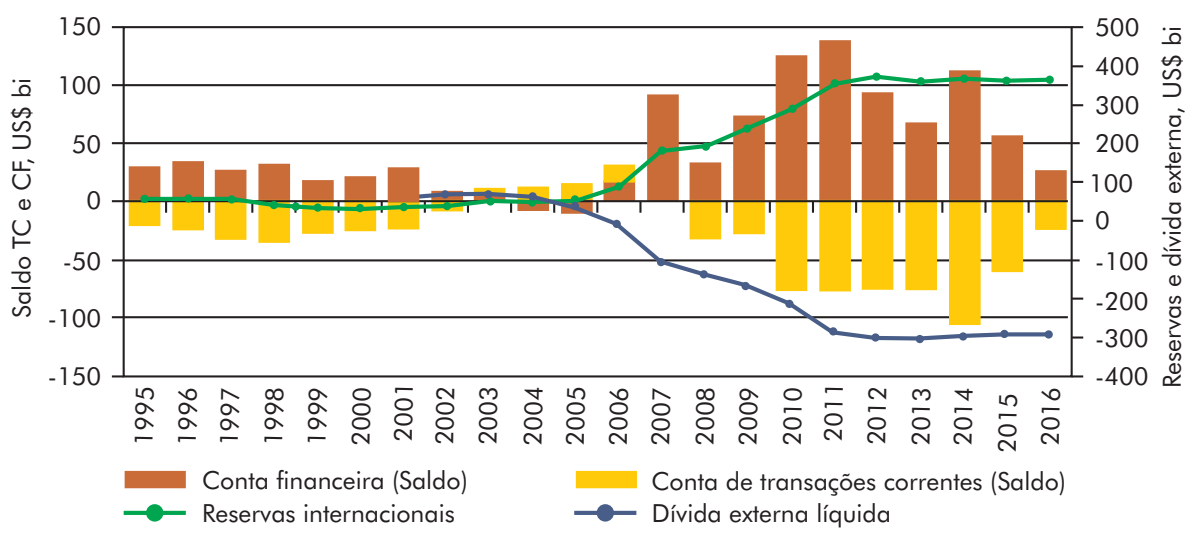

Fonte: Elaboração própria com base em dados de BCB.

Entretanto, a contrapartida da acumulação de reservas internacionais, especialmente entre 2006 e 2011, foi o expressivo aumento das operações compromissadas, aumentando a dívida bruta interna do governo geral (Tabela 2). De fato, o Gráfico 5 demonstra a existência de uma relação bastante estreita entre o crescimento das reservas internacionais e das operações compromissadas no Brasil, particularmente entre 2006 e $2009^{9}$. Entre 2011 e 2014, por sua vez, o crescimento das reservas internacionais diminuiu em relação ao crescimento médio verificado no interregno anterior, tendo passado de US\$ 352 bilhões para US\$ 364 bilhões. Já as operações compromissadas realizadas pelo BCB para fins de política monetária subiram de R $\$ 342$ bilhões para R\$ 809 bilhões. Essa elevação pronunciada dessas operações decorreu tanto da política de administração da dívida pública mobiliária federal interna pelo Tesouro Nacional, orientada para reduzir a indexação da parcela da referida dívida à taxa Selic ${ }^{10}$, como do desaquecimento da economia e da menor demanda por crédito bancá-

9 A exceção foi o ano de 2010, quando as operações compromissadas caíram para R \$288,7 bilhões, ante R\$ 454,7 bilhões em 2009. Esse movimento, contudo, refletiu a política de recolhimento compulsório realizada pelo BCB. Isso porque com a deflagração da crise global, em setembro de 2008, o BCB flexibilizou a política de recolhimento. Isso, inclusive, condicionou o aumento do saldo das operações compromissadas entre 2008 e 2009. Já em 2010, o BCB aumentou substancialmente o recolhimento compulsório, reduzindo a necessidade de o BCB realizar operações de mercado aberto, via operações compromissadas, para "enxugar liquidez" do sistema. Ver, por exemplo, Pellegrini (2011, p. 22-23).

${ }^{10}$ Essa estratégia do TN pode ser apurada pelo Plano Anual de Financiamento (PAF), publicados pela instituição, a partir de 2012. Desde então, a política do TN consistiu em não renovar toda a parcela vincenda de Letras Financeiras do Tesouro (LFTs), papéis indexados à taxa Selic. Essa estratégia, contudo, 
rio, o que fez aumentar a liquidez no mercado interfinanceiro e, assim, exigir a realização de operações compromissadas pelo BCB para "enxugar” a liquidez e atingir a meta para a taxa Selic ${ }^{11}$.

Gráfico 5 - Reservas internacionais e operações compromissadas (2003-2016)

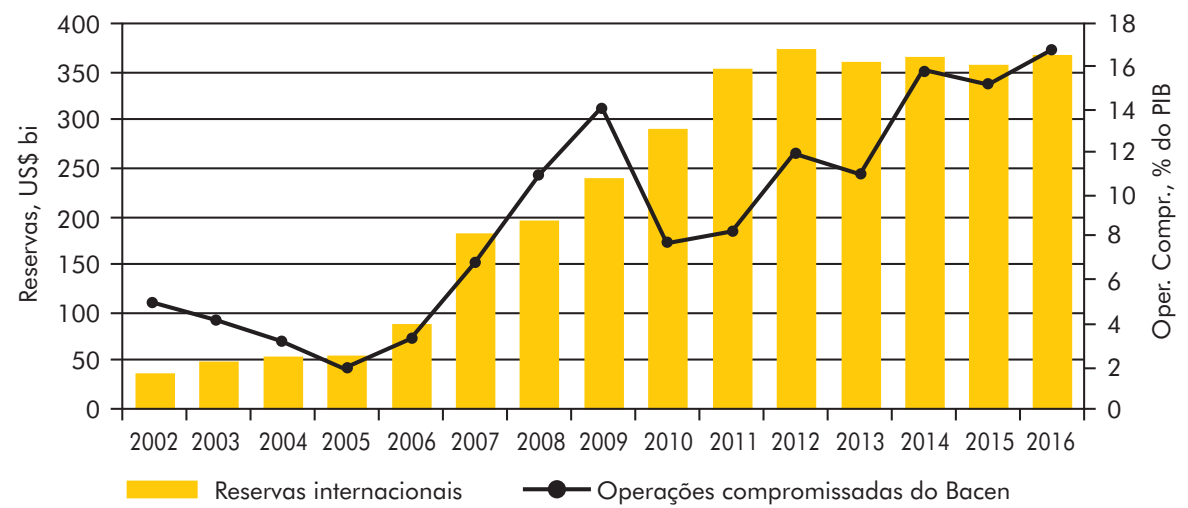

Fonte: Elaboração própria com base em dados de BCB.

\subsection{PERÍODO 1995-2002}

A lógica do plano de estabilização dos preços no Brasil que prevaleceu entre julho de 1994 e janeiro de 1999, baseada na âncora cambial e na prática de juros extremamente elevados, provocou uma expressiva deterioração das contas públicas ${ }^{12}$ (CARVALHO, 2000; LOPREATO, 2013). Isso ocorreu mesmo com o forte aumento da carga tributária bruta, que passou de $26 \%$ para $32,1 \%$ entre 1995 e $2002^{13}$. No período, a DLSP/PIB subiu de $28 \%$ para 59,8\%. É importante observar, contudo, que o papel da carga de juros no processo deterioração das contas públicas no Brasil é pouco discutido ou até

aumentou a necessidade de operações de mercado do BCB, via compromissadas, para viabilizar o alcance de sua meta operacional, vale dizer, de taxa básica de juros.

11 Com a deterioração das condições macroeconômicas a partir de 2012, especialmente de 2014 em diante, verificou-se uma expressiva desaceleração das operações de crédito, tornando o sistema bancário mais líquido. Isso também contribuiu para o aumento das operações compromissadas, de sorte a viabilizar o alcance da meta da taxa Selic pelo BCB. Somente entre 2013 e 2014, quando o PIB cresceu apenas 0,15\%, as operações compromissadas aumentaram de $\mathrm{R} \$ 529$ bilhões para R 809 bilhões.

12 A despeito, vale salientar, do fato de o equilíbrio das contas públicas constituir uma prioridade da estratégia de estabilização da economia no âmbito do Plano Real

13 Dados calculados pelo IBGE, cuja série histórica vai de 1947 a 2011. 
mesmo refutado por economistas que se destacam na discussão sobre o tema no Brasil, como Giambiagi (2007), Giambiagi e Pinheiro (2012) e Almeida Jr. (2015) ${ }^{14}$.

Como mostra a Tabela 1, entre 1996 e 1998 o país apresentou deficit fiscal primário. Isso, em um contexto de juros nominais elevados, aumentou a dívida líquida de $28 \%$ para quase $38,9 \%$ do PIB. Esse crescimento foi causado pelo aumento da dívida líquida interna, que passou de $22,9 \%$ para $28,7 \%$ do PIB, com a dívida líquida externa tendo caído de 5,1\% para 4,0\% do PIB. A prática de taxa de juros reais elevadas, subproduto da própria lógica do plano de estabilização com âncora cambial foi, em última instância, o fator determinante da deterioração das contas públicas brasileiras em um curto espaço de tempo (CARVALHO, 2000).

Nesse interregno, a situação das contas públicas foi administrável enquanto as condições externas foram favoráveis, com alta liquidez e baixas taxas de juros internacionais, em um contexto de patamar inicial ainda relativamente baixo da DLSP. Tratou-se, entretanto, de uma situação temporária.

A tentativa de preservar a âncora cambial diante da crise da Ásia, em 1997, e da Rússia, em 1998, exigiu a prática de taxas de juros ainda mais elevadas, aumentando rápida e pronunciadamente o deficit fiscal nominal e, por extensão, a dívida bruta. Em 1999, o sistema de âncora cambial tornou-se insustentável. A crise cambial do final da década de 1990 agravou ainda mais as contas públicas brasileiras, em vista da elevada parcela da dívida pública indexada ao câmbio e à taxa Selic, pressionando a dívida interna ${ }^{15}$. Além disso, a desvalorização cambial elevou o valor da dívida externa em moeda nacional, que, inclusive, havia crescido em razão dos empréstimos recebidos do FMI para tentar preservar a âncora cambial frente à deterioração das contas externas ${ }^{16}$. Por fim, a redução das reservas internacionais levou a um aumento da DLSP, na medida em que ela significou uma redução de seus créditos ou ativos.

Com o colapso da âncora cambial, a partir de meados de 1999 foi adotado o regime de metas para a inflação no Brasil, exigindo do governo a geração de superavit

${ }^{14}$ Pinheiro e Giambiagi (2006, p. 111), por exemplo, fazem menção ao fato de países com relação dívida pública / PIB maior do que 100\% também terem despesas com juros em torno de $10 \%$ do PIB, tais como Itália, Grécia e Bélgica. Não obstante, esses países, além de muito diferentes entre si, são extremamente diferentes do Brasil, especialmente no que diz respeito ao grau de desigualdade de renda e do tamanho da população em condições de miséria e pobreza. Ademais, mas não menos importante, com exceção da Grécia, cuja população é menor do que a da cidade de São Paulo, Itália e Bélgica possuem patamares de carga tributária (impostos mais contribuições) mais elevados do que o Brasil, sendo que a participação dos impostos sobre a renda e a propriedade também é maior, relativamente aos incidentes sobre bens e serviços. Dessa forma, esses países têm um sistema tributário bem mais justo do que o brasileiro.

15 A indexação dos títulos públicos às taxas de juros, câmbio e inflação faz com que flutuações nessas variáveis afetem diretamente o endividamento público (OLIVEIRA e CARVALHO, 2010; OLIVEIRA, 2010a).

16 Vale lembrar que país recorreria mais duas vezes ao FMI até 2002. 
fiscais primários elevados para fazer frente ao serviço da dívida pública. O Programa de Estabilidade Fiscal (PEF) apresentado no final de 1998 foi o embrião do regime de metas para o superavit fiscal primário que seria institucionalizado pela Lei de Responsabilidade Fiscal (LRF) de 2000, o qual pressupunha a fixação do superavit primário necessário para assegurar a trajetória desejada da relação DLSP/PIB.

A construção do novo regime fiscal assegurou a geração de superavit primários elevados, sobretudo a partir de 1999 (Tabela 1). Dado o baixo crescimento econômico verificado no período, de um lado, e o crescimento da despesa primária acima do PIB, de outro, a geração desses superavit deu-se principalmente mediante aumento da carga tributária, que aumentou de 27,9\% para 32,1\% entre 1999 e 2002 . Entretanto, isso não foi capaz de evitar o crescimento da DBGG/PIB entre 1999 e 2002, em função do efeito desfavorável que a desvalorização da taxa de câmbio, o aumento da taxa de inflação e a elevação da taxa de juros exerceram sobre a dívida bruta. Tampouco foi capaz de impedir a elevação da DLSP/PIB, em razão da redução do nível das reservas internacionais ${ }^{17}$. Giambiagi (2007), embora reconheça que a geração de superavit fiscal primário teve um efeito bastante modesto em termos de redução da relação DLSP/PIB naquele período, não reconhece devidamente o papel desempenhado pelos juros da dívida pública para essa resistência à queda da razão mencionada.

A Tabela 1 mostra que o objetivo da âncora fiscal não foi alcançado, ao menos com a rapidez e a magnitude que se esperava. Embora entre 1999 e 2002 o superavit fiscal primário tenha permanecido acima de $3 \%$ do PIB, a manutenção de juros nominais elevados impediu uma queda significativa do deficit fiscal nominal. A DLSP aumentou de $44,5 \%$ para $59,8 \%$ do PIB, dessa vez pressionada não apenas pela dívida líquida interna, que passou de $35,2 \%$ para $44,3 \%$ do PIB, mas também pela dívida líquida externa, que aumentou de $9,4 \%$ para $15,2 \%$ do PIB no período. Isso significa, pois, que a política de geração de superavit fiscais primários implementada a partir do final da década de 1990 não foi capaz de reverter o aumento significativo da razão DLSP/PIB, pois os movimentos adversos das taxas de juros, de câmbio e de inflação, decorrentes de um contexto externo e interno desfavorável, neutralizaram o efeito positivo desses superavit obtidos no período. Destarte, obtenção de superavit fiscais primários elevados e sistemáticos não foi suficiente para viabilizar a redução tanto da DBGG/PIB como da DLSP/PIB no Brasil até 2002.

\footnotetext{
17 Vale lembrar que os primeiros anos da década de 2000 foram marcados por condições externas desfavoráveis, como a crise argentina, a queda da bolsa de alta tecnologia e os ataques terroristas nos Estados Unidos, bem como por condições internas adversas, como a crise energética e, principalmente, as incertezas em relação à eleição presidencial.
} 
De fato, entre 1995 e 1998, observou-se uma importante deterioração dos indicadores fiscais no Brasil, tanto no que se refere ao deficit público como no que diz respeito à dívida pública, diante da prática de juros elevados, do baixo crescimento econômico e da ausência da política de geração de superavit fiscais primários. Já o período 1999-2002 foi marcado pela mudança dos regimes cambial, monetário e fiscal. Na prática, inaugurou-se um novo modelo de gestão das contas públicas, baseado na política de geração de superavit fiscais primários. Não obstante, naquele período, isso não foi suficiente para evitar um expressivo crescimento da DLSP/PIB.

Com isso, não se quer dizer que o crescimento dos gastos primários não tenha desempenhado, também, papel importante para o aumento da razão DLSP/PIB no Brasil, particularmente entre 1995 e 2002 . A despesa primária do governo central, de fato, aumentou depois do Plano Real, tendo passado de 13,9\% para 15,7\% do PIB entre 1994 e 2002, como mostra Almeida Jr. (2015). Em 2014, ela era de 20,1\%. E, certamente, isso decorreu das elevadas demandas efetiva e potencial por serviços públicos em uma sociedade altamente desigual do ponto de vista socioeconômico como a brasileira. Tanto é que, como mostra Almeida Jr. (2015), entre 1991 e 2014 cerca de 80\% do crescimento das despesas primárias decorreram de programas de transferência de renda. Evidentemente, também concorreu para o aumento do endividamento: i) certo grau de ineficiência das despesas, como indicam Giambiagi e Pinheiro (2011); ii) a prociclicidade dos gastos públicos, em razão da indexação dos gastos à inflação passada e da destinação obrigatória das despesas, como mostra Mendes (2014; 2015); iii) a prociclicidade da gestão da dívida pública mobiliária federal interna, decorrente da existência de diversos indexadores e da institucionalidade da indexação financeira, como mostram Oliveira e Carvalho (2010); e iv) o fato de que o investimento em infraestrutura, necessário para o desenvolvimento do país, também enseja a elevação das despesas primárias. Afinal, não é possível construir escolas e hospitais públicos e não se dispor de pessoal para viabilizar o atendimento aos usuários. De qualquer modo, não é possível minimizar a deterioração das contas públicas suscitada notadamente pela carga de juros elevada incidente sobre a dívida pública, como faz, por exemplo, Giambiagi $(2007)^{18}$, cujo impacto em termos de NFSP chegou a ultrapassar $8 \%$ do PIB em alguns anos depois do Plano Real.

18 Para sustentar a tese de que os juros não deterioraram as contas públicas no Brasil pós-Real, Giambiagi (2007) argumenta que a carga de juros, na comparação com dados mais antigos, não mudou muito no Brasil. Contudo, as diferenças metodológicas entre as séries de dados requerem muita cautela nesse tipo de comparação. Além disso, mas não menos importante, mesmo que a carga de juros tenha se mantido no mesmo patamar, isso não significa que ela não tenha sido uma das grandes causas, também, para a deterioração das contas públicas no Brasil. De igual modo, reconhecer isso não implica deixar de reconhecer 
Deve-se salientar, ainda, que esse crescimento das despesas primárias acima do PIB não inviabilizou a geração de superavit fiscal primário entre 1999 e 2002, bem como nos anos subsequentes até 2013. Ocorre, contudo, que os resultados fiscais primários obtidos pelo setor público consolidado foram insuficientes para arcar com a carga de juros incidente sobre a dívida pública. De qualquer modo, há que se reconhecer que não fosse o contexto internacional altamente benigno para o Brasil, do ponto de vista do influxo de capitais e dos preços das commodities, que prevaleceu entre 2004 e 2008, bem como entre 2010 e 2013, certamente o resultado fiscal primário teria sido bastante inferior ao observado e, em alguns anos, até mesmo negativo.

\subsection{PERÍODO 2003-2008}

Entre 2003 e 2008 - até o final do terceiro trimestre, quando da deflagração da crise internacional -, as condições externas excepcionalmente favoráveis contribuíram de forma decisiva para que a economia brasileira fosse capaz de conciliar elevação do ritmo de crescimento econômico e baixa taxa de inflação, de um lado, e superavit em transações correntes (com exceção de 2008) do balanço de pagamentos e expressiva redução tanto da DLSP/PIB como da DBGG/PIB, de outro.

Esse contexto altamente benigno deveu-se a dois fatores principais, a saber: i) o aumento do superavit comercial, decorrente da elevação não apenas da quantidade, mas também e, principalmente, dos preços das commodities exportadas pelo país; e ii) o expressivo ingresso de capital estrangeiro para a economia brasileira, seja sob a forma de investimentos diretos seja de portfólio, como consequência da ampla liquidez e das baixas taxas de juros internacionais.

Entre 2003 e 2008, as reservas internacionais do Brasil aumentaram de US\$ 49 bilhões para US\$206,8 bilhões. Esse aumento foi substancialmente influenciado pelo saldo líquido da conta financeira do balanço de pagamentos, vale dizer, dos investimentos estrangeiros diretos e, principalmente, dos investimentos em portfólio (OLIVEIRA, 2010b).

Esse processo concorreu para valorizar expressivamente a taxa de câmbio ao longo do período, até a deflagração da crise global em 2008. Nem mesmo a política de acu-

que os gastos primários cresceram em ritmo médio acelerado no período pós-Real. Embora, frise-se, a elevada demanda por serviços públicos em um país tão desigual como o Brasil imponha esse tipo de pressão, na medida em que se avança na consolidação da democracia no país, de um lado; e que o próprio investimento em infraestrutura, tão necessário para o desenvolvimento do país, suscita o aumento de gastos correntes adiante. 
mulação de reservas levada a cabo pelo BCB foi suficiente para evitar esse movimento. A bonança externa contribuiu substancialmente para o controle da inflação, a redução taxa de juros e a expansão do crédito, fatores estimulantes do crescimento econômico e, também, dos superavit fiscais primários elevados. Verificou-se, com efeito, redução relevante tanto da DLSP/PIB como da DBGG/PIB. A então elevada importância dos títulos públicos indexados à inflação, ao câmbio e aos juros também contribuiu para esse movimento, diante do movimento desses preços no período.

Essa queda da DBGG/PIB, vale salientar, foi reforçada pela redução da dívida externa bruta. Além da valorização da taxa de câmbio, que a reduziu em moeda nacional, o contexto externo extremamente favorável permitiu que o país honrasse os compromissos previamente assumidos com o FMI e iniciasse um processo de liquidação dos títulos públicos emitidos vincendos, como parte do esforço do governo de reduzir a exposição da dívida pública ao câmbio ${ }^{19}$.

Assim, a acumulação de reservas internacionais foi determinante para a redução da DLSP/PIB, ao permitir a liquidação de compromissos externos do setor público e o aumento dos ativos externos do setor público.

Como mostram as Tabelas 1 e 2, entre 2003 e 2008 os superavit fiscais primários continuaram acima de $3 \%$ do PIB. Isso, somado à queda da carga de juros nominais, contribuiu para a estabilização da dívida interna bruta entre 56\% e 58\% do PIB. Em verdade, a queda da dívida bruta total do governo geral, de $71,5 \%$ para $61,4 \%$ do PIB, deveu-se à forte queda dívida bruta externa, de $14,1 \%$ para $4,7 \%$ do PIB no período, em vista das mencionadas liquidações dos compromissos externos. A DLSP, por sua vez, caiu de 54,3\% para 37,6\% do PIB, o que não se deveu à redução da dívida líquida interna, que aumentou de $43,2 \%$ para $48,3 \%$ do PIB, mas, sim, à substancial queda da dívida líquida externa, de $11,0 \%$ para $-10,7 \%$ do PIB, com a reversão da posição histórica brasileira de devedor para a de credor externo líquido a partir de 2006. Evidencia-se, pois, o caráter imprescindível das condições externas excepcionalmente favoráveis para a melhora das contas públicas no Brasil no período em questão, particularmente da DBGG/PIB e da DLSP/PIB. Melhora que ocorreu mesmo diante

19 De fato, em 2005, o Brasil antecipou o pagamento de US\$ 15,5 bilhões ao FMI, o que permitiu ao país quitar a totalidade da dívida assumida junto à instituição. Naquele momento, estimou-se que isso asseguraria também uma economia de US\$ 900 milhões em pagamentos de juros ao setor público.

A partir de 2005, as operações com títulos no mercado externo foram transferidas do BCB para o TN. A partir de 2006, o TN adotou uma estratégia de redução da dívida mobiliária externa, por meio da redução do ritmo de rolagem dos títulos emitidos no âmbito do Programa de Resgate Antecipado da Dívida Externa. Essa medida foi amparada na Resolução n 20, de 2004, que autorizou o TN a utilizar as reservas internacionais em operações de recompra de títulos de dívida denominados em moeda estrangeira (buyback). 
de uma carga de juros ainda bastante elevada, de um lado, e de crescimento médio acelerado dos gastos primários, de outro.

O contexto de bonança externa contribuiu tanto para a liquidação de compromissos externos e a constituição de elevadas reservas internacionais, como para a aceleração do crescimento econômico. A Tabela 4 mostra os fatores condicionantes da razão DLSP/PIB. Verifica-se que a redução desta razão entre 2003 e 2008 está intimamente relacionada, primeiro, ao aumento do crescimento do PIB; depois, à queda da NFSP, causada mais pela redução dos juros nominais do que pelo aumento dos superavit primários; e, finalmente, pela valorização da taxa de câmbio, que afetou a dívida interna indexada a essa variável e a dívida externa expressa em moeda estrangeira. Ao contrário do que ocorreu no período de 1995 a 2002, o efeito do reconhecimento de dívidas anteriores e das privatizações do patrimônio público sobre o comportamento da razão DLSP/PIB foi praticamente nulo.

Vale enfatizar, pois, que as condições externas altamente benignas prevalecentes entre 2003 e 2008 foram imprescindíveis para a aceleração do crescimento econômico (AMITRANO, 2010). Isso explica, do ponto de vista dos fatores condicionantes da dívida pública em relação ao PIB, a maior contribuição do PIB para a redução dos dois indicadores fiscais de endividamento. Entre 2003 e 2008, as condições externas favoráveis permitiram que as políticas monetária e fiscal se tornassem menos restritivas e, assim, pudessem estimular o crescimento econômico. Esse processo apenas pôde ser sustentado, contudo, em razão do contexto internacional altamente benigno (OCAMPO, 2010).

Ocorre, contudo, que ao permitir a aceleração do crescimento e também dos gastos públicos, inclusive em razão da prociclicidade dessas despesas, como mostra Mendes (2015), quando da reversão das condições internacionais excepcionalmente favoráveis, os indicadores fiscais voltaram a apresentar sinais de piora, pois ao contexto de maiores gastos e de maior carga de juros, colocou-se uma situação de retração significativa da arrecadação. Destarte, os resultados fiscais positivos apresentados nesse intervalo, bem como em parte do subsequente, analisado a seguir, foram obtidos sem reformas estruturais, tanto do lado das receitas como do lado das despesas.

\subsection{PERÍODO 2009-2014}

A deflagração da crise internacional em setembro de 2008, com a quebra do banco de investimento americano Lehman Brothers nos EUA, interrompeu as condições externas excepcionalmente favoráveis vigentes a partir de 2003. De fato, o governo brasileiro beneficiou-se da margem de manobra propiciada pela melhora das contas externas, das contas públicas e das condições inflacionárias para adotar políticas anticíclicas. 
No plano fiscal, os investimentos públicos foram elevados, sobretudo por meio do Programa de Aceleração do Crescimento (PAC), cuja ênfase recaía sobre o setor de infraestrutura, em geral, e de saneamento, habitação, transporte e energia, em particular. Reforçou-se, ainda, a política de aumentos reais do salário mínimo, afetando toda a estrutura de rendimentos do trabalho na economia, e os programas de transferência de renda foram expandidos, tais como o Bolsa Família. Finalmente, os incentivos fiscais foram ampliados, como aqueles destinados à aquisição de bens de consumo duráveis, como automóveis e eletrodomésticos. Já no âmbito monetário, a taxa Selic foi bastante reduzida, entre meados de 2011 e meados de 2012, e o crédito foi expandido, um processo dessa vez comandado pelos bancos públicos ${ }^{20}$. Essas políticas certamente contribuíram para atenuar os efeitos da crise e, também, para viabilizar a retomada do crescimento a partir de 2010.

Com a crise, ademais, os países desenvolvidos passaram a implementar políticas monetárias altamente expansionistas, aumentando a liquidez global e propiciando a retomada dos fluxos internacionais de capital para os países da periferia ${ }^{21}$. Essa rápida e pronunciada melhora da conta financeira do balanço de pagamentos da economia brasileira foi, assim, viabilizada pelo retorno dos fluxos de capital, que promoveu a continuidade do aumento das reservas internacionais, mesmo diante da rápida e expressiva deterioração da conta de transações correntes. Entre 2008 e 2012, as reservas internacionais brasileiras aumentaram de US\$206,8 bilhões para US\$ 378,6 bilhões.

As políticas anticíclicas adotadas pelo governo brasileiro tiveram êxito em evitar os efeitos mais imediatos da crise no país e, a despeito da redução do superavit fiscal primário, os indicadores de endividamento do setor público, tanto da DLSP/PIB como da DBGG/PIB, não apresentaram deterioração enquanto, de um lado, a farta liquidez internacional viabilizou a prática de juros nominais de um dígito entre meados de 2009 e o final de 2013, atenuando o pagamento de juros da dívida pública, e, de outro, a economia cresceu e, portanto, as receitas fiscais aumentaram. Entre 2010 e 2014, enquanto a DLSP/PIB caiu de $38 \%$ para $32,6 \%$, a DBGG/PIB oscilou de $62,4 \%$ para

${ }^{20}$ Neste contexto, destacaram-se as atuações do Banco do Brasil (BB), da Caixa Econômica Federal (CEF) e do Banco Nacional de Desenvolvimento Econômico e Social (BNDES).

${ }^{21}$ Com o intuito de estimular a recuperação de suas economias, esses países lançaram mão de programas de "afrouxamento monetário", que consistiam na aquisição de títulos públicos e privados na carteira do sistema bancário por meio da criação de moeda. Nos Estados Unidos, ele iniciou-se em 2008 e terminou em 2014, tendo um total de mais de dois trilhões de dólares. No Reino Unido, ele iniciou-se em 2009, atingindo 375 bilhões de libras em 2012 e se mantendo nesse nível desde então. No Japão, ele iniciou-se em 2010, atingindo 80 trilhões de ienes em 2015. Na zona do euro, ele iniciou-se em 2015, prosseguindo em curso até a conclusão desse artigo. 
61,6\%. Considerando-se a DLGG/PIB, houve um recuo de $38,5 \%$ para $33,2 \%$ entre 2010 e 2014.

Contudo, a prociclicidade das despesas e as desonerações fiscais adotadas, juntamente com a prociclicidade da gestão da dívida pública, apontavam para um cenário preocupante, na medida em que foi se verificando uma deterioração progressiva do resultado fiscal primário entre 2011 e 2014, que culminou com um deficit de 0,6\% do PIB em 2014 (Tabelas 1 e 2).

Além do deficit quase-fiscal decorrente da continuidade da ampliação das reservas internacionais entre 2009 e 2012, em razão do custo decorrente do diferencial de taxa de juros interna e externa, o TN realizou grandes aportes de recursos nas instituições financeiras públicas, sobretudo no $\mathrm{BNDES}^{22}$. Embora essas operações realizadas pelo TN não exerçam impacto sobre a DLSP, com exceção daquele provocado pelo deficit quase-fiscal, elas pressionam a DBGG para cima.

Com a retração da economia, passou-se a verificar uma redução do superavit fiscal primário, o que, em um contexto de juros nominais crescentes, produziu um aumento do deficit nominal. Isso, então, pressionou a dívida bruta interna para cima, o que contribuiu de forma importante para o Brasil perder o grau de investimento conquistado em $2008^{23}$. Esse movimento, inclusive, condicionou a implementação de um programa de ajuste fiscal a partir de $2015^{24}$.

De acordo com a Tabela 4, entre 2008 e 2014, a redução do superavit fiscal primário e o aumento dos juros nominais, que, juntos, contribuíram para o aumento da necessidade de financiamento do setor público, exerceram impacto cada vez mais negativo sobre a variação da DLSP. Já o efeito positivo do crescimento do PIB passou a ser cada vez menos relevante no período. Por fim, o impacto da variação da taxa de câmbio sobre a DLSP foi, em geral, positivo, tanto em termos da dívida interna como em termos da dívida externa. Mais uma vez, o impacto de privatizações e do reconhecimento de dívidas sobre a variação da DLSP foi praticamente nulo.

22 Esses aportes passaram a ser a principal fonte de recursos do banco, superando a importância dos recursos do FAT/PIS-Pasep, que tradicionalmente ocupavam essa posição. Os empréstimos do TN ao BNDES foram de R\$ 100 bilhões em 2009 e acumularam quase R\$ 455 bilhões até 2014

${ }^{23}$ Em setembro de 2015, a agência Standard and Poor's reduziu a nota do Brasil, que perdeu a condição de "grau de investimento", em grande medida por conta da deterioração dos indicadores fiscais do país.

${ }^{24}$ Com a recessão e a dificuldade de viabilização de superavit fiscal primário mais elevado, o efeito sobre a dívida bruta não foi pior apenas em função da queda da dívida bruta externa, decorrente da manutenção do Programa de Resgate Antecipado da Dívida Externa levada a cabo pelo TN. Além disso, o efeito da desvalorização da taxa de câmbio sobre a dívida externa bruta foi mais do que compensado pela redução da dívida externa líquida, em função do aumento do valor das reservas internacionais em moeda nacional. 
De todo o modo, entre 2009 e 2014 a redução da DLSP/PIB deixou de ser acompanhada por uma melhora, na mesma magnitude, da DBGG/PIB. Diferentemente do contexto anterior, a saber, 2003-2008, em que o abatimento da dívida externa bruta contribuiu substancialmente para a queda da razão DBGG/PIB, a partir de 2009 esse efeito foi substancialmente reduzido, inclusive em razão do expressivo recuo da dívida externa bruta do governo geral, que passou de 14,1\% para 3,3\% entre 2003 e 2014 . Estava claro que, com o aprofundamento da crise, o quadro fiscal no Brasil sofreria uma reversão significativa, o que, de fato, aconteceu já a partir de 2014.

\subsection{PERÍODO 2015-2016}

O biênio 2015-2016 foi marcado pela elevada instabilidade política e econômica no Brasil, que culminou com o impeachment da então presidente Dilma Roussef da Presidência da República, em agosto de 2016. Desde que assumiu o cargo, o até então Vice-Presidente da República Michel Temer tem buscado levar a cabo um conjunto de medidas de ajuste fiscal, dentre as quais se destacam a imposição de teto para o gasto público e reforma da previdência social.

A desagregação do PIB sob a ótica da despesa mostra que a retração do investimento iniciada a partir do quarto trimestre de 2013 não foi compensada pela expansão do gasto público, diferentemente do que ocorreu no contexto da deflagração da crise global em 2008 (Gráfico 6). Isso porque, diferentemente de 2008, a partir de 2013 o espaço fiscal para a realização de política fiscal anticíclica foi reduzido substancialmente, inclusive em razão de a política fiscal anticíclica iniciada em 2008 não ter sido devidamente contida quando da retomada do investimento privado. Entre 2008 e 2014, como mostra Almeida Jr. (2015), a despesa primária do governo central aumentou de $16,42 \%$ para $20,08 \%$.

Com a crise e, consequentemente, a substancial retração do PIB e, com efeito, a abrupta piora da arrecadação fiscal, as contas públicas apresentaram piora significativa: entre 2014 e 2016 o resultado fiscal primário passou a apresentar deficit crescente. Combinado com a elevada carga de juros nominais, que atingiu nada menos que $8,4 \%$ em 2015, isso ocasionou deficit nominais expressivos: 6\% em 2014; 10,2\% em 2015; e $9 \%$ em 2016 (Tabela 1). Os indicadores de endividamento também pioraram sensivelmente, nesse contexto. Entre 2014 e 2016, a DLSP/PIB aumentou de 32,6\% para 46,2\%, enquanto a DBGG/PIB subiu de $61,6 \%$ para $77,5 \%$. Com a recessão, como adverte Pellegrini (2017), o crescimento do PIB deixou de contrapesar a carga de juros da DBGG, o que concorreu para aumentar substancialmente a razão DBGG/PIB. Esse contexto, ainda segundo o autor, tende a continuar pressionando a referida razão para 
cima nos próximos anos, especialmente na ausência de iniciativas orientadas para viabilizar a retomada do crescimento econômico e a geração de superavit primários, conformando um cenário de indefinição sobre a sustentabilidade da dívida pública.

Gráfico 6 - PIB e seus componentes de despesa (em variação \% anual, 1997-2016)

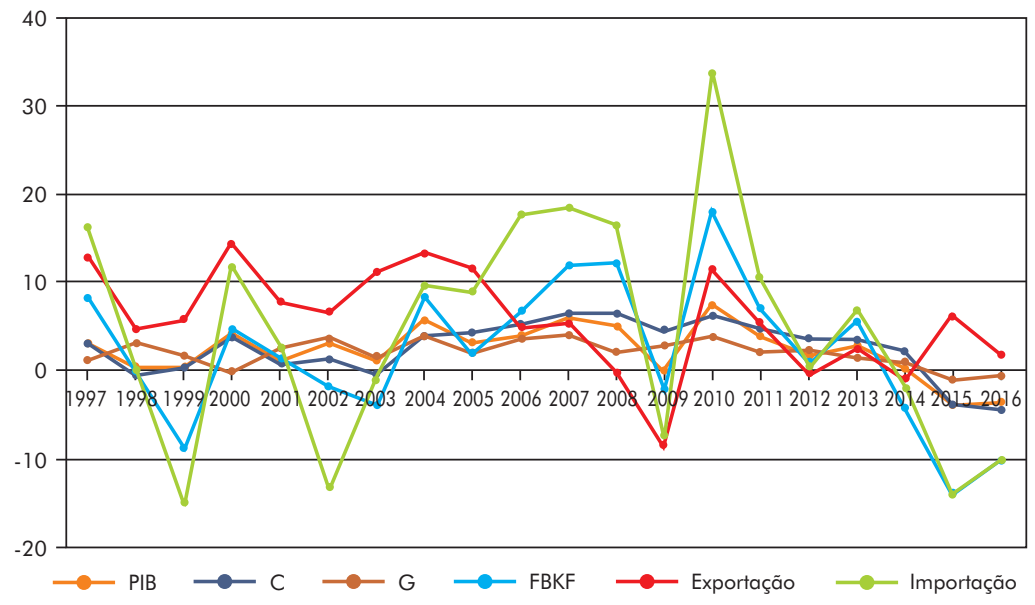

Fonte: Elaboração própria com base em dados do IBGE (Contas Nacionais Trimestrais).

A crise, dessa forma, explicitou a fragilidade das contas públicas no Brasil, fragilidade essa que foi ocultada durante o período em que durou a bonança internacional, explicitando ao menos três características importantes da dinâmica fiscal no país, a saber: i) dificuldade de implementação de política fiscal anticíclica, inclusive em razão da prociclicidade dos gastos públicos; ii) crescimento das despesas primárias em ritmo mais acelerado do que o crescimento do PIB, apontando para um desajuste problemático entre receitas e despesas em contexto de adversidades, considerando a atual estrutura de receitas e despesas do setor público brasileiro; e iii) elevado peso imposto pela carga de juros sobre a dívida pública, dificultando, também por essa via, a realização de política fiscal anticíclica. Entre 2014 e 2015, diante do aumento da taxa de juros realizada pelo $\mathrm{BCB}$ para fazer os preços convergirem para a meta estipulada para a inflação, os gastos com juros aumentaram de $6 \%$ para 10,2\% do PIB. Com 10,2\% do PIB, por exemplo, seria possível ampliar em vinte vezes o programa bolsa família. Ou seja, não se pode afirmar que os gastos sociais não cabem no orçamento público em um país onde se gasta entre $6 \%$ e $10 \%$ do PIB anualmente com juros da dívida pública, contra $0,5 \%$ do PIB com o maior programa de transferência de renda do mundo (bolsa família); onde a desigualdade de renda é uma das maiores do mundo, mesmo com o Brasil estando entre as dez maiores economias do planeta. 
Em direção contrária, Giambiagi (2015) e Netto (2017), por exemplo, sugerem que o pacto social estabelecido pela Constituição Federal (CF) de 1988 concede direitos sociais excessivos diante dos limites do orçamento público brasileiro. Contudo, decerto são os privilégios ainda existentes nos sistemas de arrecadação e gastos (nas esferas do executivo, do legislativo e do judiciário) do ultrapassado modelo fiscal brasileiro, bem como as ineficiências provocadas por um sistema político anacrônico e pouco funcional do ponto de vista social, baseado no fisiologismo político e na "troca de favores" (leia-se, emendas e concessões diversas), que não cabem no orçamento público.

Isso não significa, evidentemente, que o crescimento econômico não requer aumento da produtividade média dos fatores de produção, tampouco que não haja problemas de "desenhos de incentivos" decorrentes de escolhas políticas dos diferentes governos, como afirmam Netto (2017) e Giambiagi (2015), respectivamente. Porém, o enfrentamento da questão fiscal não deve incidir apenas sobre os segmentos mais vulneráveis da sociedade e, por isso, com menor poder de fazer prevalecer as suas preferências.

Segundo Pellegrini (2017), "O país defronta-se com o grande desafio de controlar uma dívida pública crescente e em níveis inéditos, o que requer a adoção com urgência de um amplo conjunto de medidas de ajuste que envolva todo o setor público. [...]”. Inclusive em um país cujos gastos com serviços essenciais, como é o caso das áreas da saúde e da educação, são relativamente muito menores do que em outros países, situação que torna os problemas sociais ainda mais crônicos sob a condição de subdesenvolvimento socioeconômico.

No conjunto do período pós-Real, pois, o quadro de persistente deficit fiscal nominal foi absorvido parte pelo aumento do endividamento do setor público e parte pelo aumento da carga tributária, que subiu de $26 \%$ para $34 \%$ entre 1995 e $2011^{25}$. Donde a ausência de uma agenda positiva de reforma fiscal, orientada para tornar o sistema tributário mais justo e eficiente, de um lado, e tornar as despesas menos rígidas e procíclicas, bem como mais adaptadas às transformações demográficas pelas quais o país tem passado, de outro, tem imposto, no período mais recente, um programa de ajuste fiscal rigoroso e ditado, em grande medida, pelo mercado. Situação esta, frise-se, subproduto da falta de reformas estruturais e democraticamente pactuadas nos governos FHC, Lula e Dilma, também porque submetidos a um sistema político anacrônico e ineficiente, por todos eles não enfrentado.

${ }^{25}$ Dados calculados pelo IBGE, cuja série histórica vai de 1947 a 2011. De acordo com a Receita Federal do Brasil (RFB, 2016), contudo, em 2011 a carga tributária bruta era de 33,4\%, tendo atingido 32,7\% em 2015. 


\section{CONCLUSÃO}

O artigo realizou um balanço crítico da dimensão fiscal da economia brasileira desde o Plano Real, particularmente no que diz respeito às NFSP e ao endividamento do setor público brasileiro, a partir de indicadores selecionados, destacando a importância das condições externas benignas para a melhora dos indicadores fiscais no Brasil. Nessa perspectiva, o trabalho se diferencia dos demais sobre o tema por incluir, de forma central, a dimensão do contexto internacional na análise das contas públicas, tanto de forma direta como indireta. De maneira direta, no sentido de mostrar que a redução da razão DLSP/PIB decorreu da redução da DELSP, a qual, por sua vez, resultou da acumulação de reservas internacionais propiciada tanto pelo influxo de divisas pela conta financeira do balanço de pagamentos como pelo aumento das exportações decorrente da elevação excepcional dos preços das commodities exportadas pelo Brasil. De forma indireta, portanto, no sentido de chamar a atenção para o fato de que, embora ainda relativamente fechada do ponto de vista da corrente de comércio, o contexto externo benigno que prevaleceu entre 2004 e 2008 e, depois da crise, entre 2010 e 2014, foi altamente relevante para acelerar o ritmo de crescimento do PIB, tanto do ponto de vista da entrada de recursos externos para aquisição de ativos como das exportações de commodities.

Isso permitiu verificar que a expressiva redução da DLSP/PIB entre 2002 e 2013 decorreu da diminuição da DELSP, proveniente do acúmulo de reservas internacionais. A DLSP/PIB também diminuiu nesse período, evidentemente, em razão do crescimento do PIB e do aumento arrecadação tributária. Mas, como argumentado, tanto o acúmulo de reservas internacionais como o crescimento do PIB e, conseguintemente, da arrecadação tributária, foram viabilizados, em boa medida, pelo contexto internacional altamente benigno para o Brasil, decorrente tanto dos preços elevados das commodities exportadas pelo país como pelo ingresso de investimento estrangeiro direto e em carteira. Ficou mais claro, dessa forma, que: i) não fosse a redução da DELSP e o crescimento do PIB, ambos propiciados, em grande medida, pelo contexto internacional altamente benigno verificado nesse intervalo, a razão DLSP/PIB não teria diminuído; e ii) a DBGG/PIB também não teria registrado redução nesse período se não tivesse ocorrido tanto a contração da relação Dívida Bruta Externa do Governo Central (DBEGC)/PIB como o crescimento econômico.

A análise realizada, cumpre salientar, permitiu identificar quatro períodos distintos, tendo-se em vista as trajetórias do deficit público e da dívida pública, ambos em relação ao PIB, a saber, de 1995 a 2002, de 2003 a 2008, de 2009 a 2014 e de 2015 a 2016. Em todos eles, ainda que sob diferentes magnitudes, a despesa primária do governo central cresceu acima do PIB; verificou-se deficit nominal do setor público con- 
solidado; a carga de juros nominais sobre a dívida pública foi bastante elevada, superando sempre, quando houve, o superavit fiscal primário.

O artigo mostrou, dessa forma, o caráter imprescindível das condições internacionais para a melhora das condições das contas públicas no Brasil depois do Plano Real, considerando tanto os indicadores de necessidade de financiamento (fluxo) como de endividamento (estoque). Não fossem tais condições, decerto a incidência de uma carga de juros muito elevada sobre a dívida pública, de um lado, e o ritmo acelerado de crescimento das despesas primárias, acima do crescimento do PIB, de outro, teriam imposto uma situação fiscal inviabilizadora dos programas de transferência de renda e da política de aumento do salário mínimo real levada a cabo entre 2003 e 2014.

Os efeitos das condições internacionais altamente benignas foram muito marcantes no caso da trajetória da relação DLSP/PIB ao longo do período 2004-2014. Mesmo depois da deflagração da crise internacional no início do terceiro quadrimestre de 2008, esse importante indicador de solvência do setor público permaneceu em uma trajetória de queda até 2014. Isso em função, em larga medida, da continuidade do processo de ampliação das reservas internacionais, entre 2009 e 2012, da obtenção de superavit fiscais primários ainda razoáveis, da boa recuperação dos preços das commodities e do crescimento econômico. $\mathrm{O}$ mesmo, contudo, ocorreu de forma bem mais moderada com a relação DBGG/PIB, uma vez que a trajetória de declínio desse indicador entre 2003 e 2008 decorreu, fundamentalmente, da redução da dívida externa bruta, sendo que a partir de 2009 os compromissos externos do governo geral já se encontravam em patamares bastante baixos. Como visto, contudo, a DBGG constitui um indicador mais robusto de solvência do setor público, na medida em que a maior parte dos ativos do setor público não é passível de ser utilizado, no curto prazo, para diminuir o endividamento público, tal como sustentado por Pellegrini (2017).

Nessa perspectiva, no período mais recente novos e complexos desafios passaram a se colocar no âmbito das contas públicas no Brasil, considerando o contexto internacional bastante diferente daquele que prevaleceu entre 2003 e 2008, de um lado, e as pressões cada vez maiores por um ajuste fiscal capaz de reestabelecer o alcance de $s u$ peravit fiscais primários nos níveis observados entre 1999 e 2008, em um contexto de recessão econômica, de outro. De fato, uma dinâmica de gasto fiscal primário em ritmo acelerado, também decorrente da prociclicidade das despesas públicas, e uma carga de juros excepcionalmente elevada, apenas se mostraram sustentáveis em um contexto internacional altamente benigno, que permitiu o abatimento da dívida externa e a aceleração do crescimento econômico. Findo esse processo, os indicadores fiscais sofreram expressiva deterioração, de fluxo e de estoque, ensejando a realização de um rigoroso ajuste fiscal com perfil ditado pelo mercado, cujas maiores marcas foram a aprovação da PEC do Teto dos Gastos Públicos e a agenda de reformas traba- 
lhista e da previdência. Esse tipo de ajuste é, em boa medida, decorrente da inépcia dos diferentes governos em relação ao enfrentamento da questão fiscal a partir de reformas estruturantes e progressistas do ponto de vista econômico e social.

\section{REFERÊNCIAS}

AKYUZ, Y. Impasses do desenvolvimento. Novos Estudos Cebrap, São Paulo, n. 72, 2005.

ALMEIDA JR., M. F. Crescimento econômico e dilemas fiscais. Encontro IBEF 2015, 30 mai. 2015. Disponível em: <ibefes.org.br/faq/>. Acesso em: 30 out. 2016.

AMITRANO, C. R. "O regime de crescimento econômico brasileiro: uma apreciação sobre o período 1995-2009”. In: IPEA - INSTITUTO DE PESQUISA ECONÔMICA APLICADA. Brasil em desenvolvimento: Estado, planejamento e políticas públicas. 1. ed. v. 1. Brasília: IPEA, 2010. p. 55-84.

BCB - BANCO CENTRAL DO BRASIL. Alteração na metodologia de cálculo da dívida bruta do governo geral (DBGG). Relatório de inflação, Brasília, mar. 2008.

CARVALHO, C. E. "As finanças públicas no Plano Real”. In: CARNEIRO, R. et al. Gestão estatal no Brasil: armadilhas da estabilização. São Paulo: Fundap, 2000, p. 196-236.

GIAMBIAGI, F. Brasil, raízes do atraso: paternalismo x produtividade: as dez vacas sagradas que acorrentam o país. 4. ed. Rio de Janeiro: Elsevier, 2007.

GIAMBIAGI, F.; PINHEIRO, A. C. Além da euforia: riscos e lacunas do modelo brasileiro de desenvolvimento. Rio de Janeiro: Elsevier, 2012, p. 14-43.

GIAMBIAGI, F. Entrevista. El País, São Paulo, 19 out. 2015. Disponível em: <https://brasil.elpais.com/brasil/2015/09/22/politica/1442935579_665784.html>. Acesso em: $10 \mathrm{dez} .2016$.

IFI - INSTITUIÇÃO FISCAL INDEPENDENTE. Reservas internacionais no Brasil: evolução, nível adequado e custo de carregamento. Estudo Especial n.1, IFI, mar. 2017.

LOPREATO, F. L. C. Caminhos da política fiscal do Brasil. São Paulo, SP: Editora da UNESP, 2013.

MENDES, M. Por que o Brasil cresce pouco? Rio de Janeiro: Elsevier, 2014.

MENDES, M. Gastos procíclicos e ajuste fiscal. Valor Econômico, São Paulo, 18 mar. 2015.

NETTO, A. D. Nenhum país cresceu apenas concedendo direitos. Folha de São Paulo, São Paulo, 15 mar. 2017. Disponível em: <http://www1.folha.uol.com.br/colunas/ antoniodelfim/2017/03/1866509-nenhum-pais-cresceu-apenas-concedendo-direitos. shtml>. Acesso em: 15 mar. 2017.

OBSTFELD, M.; TAYLOR. A. M. Global capital markets: integration, crisis, and growth. Cambridge: Cambridge University Press, 2004.

OCAMPO, J. A. A macroeconomia da bonança econômica latino-americana. Revista de La Cepal, Santiago, Número Especial em Português, p. 77-99, mai. 2010.

OLIVEIRA, G. C. "Instabilidade estrutural e evolução dos fluxos internacionais de capitais privados líquidos para a periferia (1990-2009)”. In: CINTRA, M. A. M.; GOMES, K. As transformações no sistema financeiro internacional. Brasília: IPEA, 2012. 
OLIVEIRA, G. C. Moeda indexada, indexação financeira e as peculiaridades da estabilização monetária no Brasil. Economia Ensaios, Uberlândia, v. 24, p. 7-26, 2010a.

OLIVEIRA, G. C. “O mercado de capitais brasileiro no período recente: evolução e singularidades". In: MARCOLINO, L. C.; CARNEIRO, R. (Orgs.). Sistema financeiro e desenvolvimento no Brasil: do Plano Real à crise financeira. 1. ed. São Paulo: Publisher Brasil e Editora Gráfica Atitude Ltda., 2010b, p. 89-128.

OLIVEIRA, G. C.; CARVALHO, C. E. Indexação financeira e comportamento procíclico da dívida pública mobiliária federal interna no Brasil. Análise Econômica, Rio Grande do Sul, v. 28, p. 7-36, 2010.

PELLEGRINI, J. A. Dívida pública brasileira: mensuração, composição, evolução e sustentabilidade. Texto para Discussão, Núcleo de Estudos e Pesquisas da Consultoria Legislativa, Senado Federal, Brasília, n. 226, fev. 2017.

PELLEGRINI, J. A. Dívida bruta e ativo do setor público: o que a queda da dívida líquida não mostra. Textos para Discussão, Núcleo de Estudos e Pesquisas da Consultoria Legislativa, Senado Federal, Brasília, n. 95, jun. 2011.

PINHEIRO, A. C.; GIAMBIAGI, F. Rompendo o marasmo: a retomada do desenvolvimento no Brasil. Rio de Janeiro: Elsevier, 2006.

PRATES, D. O regime de câmbio flutuante no Brasil 1999-2012: especificidades e dilemas. Brasília, DF: IPEA, 2015.

RECEITA FEDERAL DO BRASIL. Carga tributária no Brasil 2015: análise por tributos e bases de incidência. Brasília: RFB, 2016.

SALTO, F.; RIBEIRO, L. Operações compromissadas, gosto de subdesenvolvimento. Valor Econômico, 08 jun. 2015. 